\title{
Pentingnya Mempelajari Administrasi dan Supervisi Pendidikan
}

\author{
Agung Syukriardi \\ Universitas Negeri Padang \\ Indonesia \\ E-mail : agungsyukriardi98@gmail.com
}

\author{
Hade Afriansyah \\ Universitas Negeri Padang \\ Indonesia \\ E-mail : hadeafriansyah@ fip.unp.ac.id
}

\author{
Rusdinal \\ Universitas Negeri Padang \\ Indonesia \\ E-mail : rusdinal@ fip.unp.ac.id
}

\begin{abstract}
Abstrak-This study aims to find out what is the importance of studying administration and supervision of education for prospective teachers. This study uses a qualitative approach with qualitative descriptive methods. The subjects of this study consisted of principals, boards of teachers and staff. Data collection consists of observation, interviews and documentation. Data analysis techniques include editing, categories, displaying data and interpretation. Conclusions in this study namely the importance of studying education administration is that we can know that the administration is an educational institution which is a major source of management in regulating the teaching and learning process in an orderly manner so that the most important goal is created at the educational institution.A profession is a position or job that demands expertise from its members. That is, it cannot be done by anyone who is not trained and is not specifically prepared to do the work. Education personnel are members of the community who are devoted and appointed to support the implementation of education. Included in the education staff are: heads of education units, educators and other education personnel.
\end{abstract}

Kata kunci -(Administrasi Pendidikan, Pendidik, Tenaga Kependidikan)

\section{PENDAHULUAN}

Administrasi merupakan suatu kegiatan berkelompok yang dapat kita lihat dimanapun disetiap organisasi. Adapun administrasi di lingkungan sekolah adalah kerja sama antara guru dengan karyawan atau para staf untuk meningkatkan proes belajar-mengajar. Adapun tujuan dari administrasi pendidikan adalah untuk mencapai tujuan dari pendidikan tersebut yaitu meningkatkan kualitas dari generasi penerus bangsa ini.

Administrasi ini sangat dibutuhkan demi kelancaran proses belajar-mengajar di dunia pendidikan, namun pada kenyataannya sebagian orang yang berada dalam lingkungan dunia pendidikan ini pengetahuan dan pengalaman akan administrasi ini sangatlah rendah. Sehingga perlu ditingkatkan lagi pengetahuan akan pentingnya administrasi di dunia pendidikan ini.

Tenaga pendidik merupakan salah satu factor yang menentukan tinggi rendahnya mutu pendidikan. Dimana tenaga pendidik memiliki tugas merencanakan dan melaksanakan proses belajar mengajar, menilai hasil belajar dari para siswa, melakukan pembinaan terhadap para siswa, melakukan penelitian yang dapat menunjang pembelajaran.

Sebagai seorang tenaga pendidik maka diharuskan memiliki kemampuan dalam menguasai materi pelajaran, penguasaan dalam memanajemen para siswa di dalam kelas, kemampuan dalam menyesuaikan diri dengan para siswa, memiliki tanggung jawab yang besar dalam melaksanakan tugasnya sebagai seorang pendidik, dan juga tenaga pendidik juga harus merupakan pribadi yang mudah berkembang dan dinamis dalam mengikuti perkembangan zaman.

Sesuai dengan yang terkandung dalam UndangUndang No. 20 Tahun 2003 tentang Sistem Pendidikan Nasional bahwa pendidik dan tenaga kependidikan memiliki kewajiban :

1. Menciptakan suasana pendidikan yang bermakna, menyenangkan, kreatif, dinamis, dan logis.

2. Mempunyai komitmen secara professional untuk meningkatkan mutu pendidikan

3. Memberi keteladanan dan menjaga nama baik lembaga, professioanal dan kedudukan sesuai dengan kepercayaan yang telah diberikan kepadanya.

Harapan dari Undang-Undang tersebut menunjukkan bahwa adanya perubahan peran dari seorang guru dimana pada mulanya guru memiliki peran sebagai pusat dari informasi bagi para siswa dan sebagai pedoman bagi para siswa dan juga selalu mendominasi kegiatan yang ada di dalam 
kelas, namun sekaran posisi guru berubah menjadi fasilitaor bagi para siswa dalam proses belajar.

\section{METODE PENELITIAN}

Metode penelitian ilmiah hendaknya disusun dengan metode dan langkah-langkah yang sistematis sehinga memudahkan melakukan penelitian. Pada artikel ini penelitian ini menggunakan metode pendekatan kualitatif dengan metode deskriptif kualitatif. Sebyek dari penelitian ini terdiri dari kepala sekolah, guru dan staf. Adapun sumber data dalam penelitian ini terdiri dri dua macam, yaitu manusia dan buka manusia. Sumber data manusia berfungsi sebagai subjek atau informasi dan data yang diperoleh melalui informasi berupa soft data (data lunak) seperti hasil wawancara dan observasi denga kepala sekolah dan guru. Sedangkan sumber data bukan manusia berupa dokumen yang relevan dengan prermasalahan penelitian seperti peristiwa atau aktifitas yang ada kaitannya dengan permasalahan penelitian. Data yang diperoleh melalui dokumen bersifat hard data yang berkenaan dengan sekolah.

\section{KAJIAN TEORI DAN PEMBAHASAN}

A. Pentingnya Mempelajari Administrasi dan Supervisi Pendidikan

Administrasi pendidikan adalah suatu proses kerjasama yang baik antara dua orang atau lebih dengan semua sumber anggota dan materi yang tersedia untuk mencapai tujuan pendidikan yang telah ditetapkan secara efektif dan efisien.

Dari pengertian diatas dapat kita tarik kesimpulan, bahwa pentinnya kita sebagai mahasiswa dan calon guru dalam mempelajari administrasi pendidikan tersebut adalah :

1. Adminstrasi merupakan suatu lembaga pendidikan yang mengtur proses belajar mengajar sehingg atujuan dari pendidikan tersebut tercapai.

2. Dapat melaksanakan porses kegiatan sesuai dengan yang telah direncanakan sehingga dapat berjalan secara efisien dan efektif.

Dengan mempelajari administrasi ini diharapkan para guru dapat melakukan perubahan yang lebih baik pada dunia pendidikan sehingga kemajuan pada dunia pendidikan di Indonesia ini dapat tercapai.

\section{B. Konsep Profesi Pendidik dan Tenaga Kependidikan \\ 1) Konsep Profesi}

Secara umum pengertian profesi adalah suatu pekerjaan yang membuthkan ilmu pengetahuab dan keterampilan khusus sehingga seseorang yang memiliki suatu pekerjaan harus mengikuti suatu pelatihan agar dapat melakukan suatu pekerjaan dengan baik.
Menurut pasal 39 A ayat 2 UUSPN No 20 Tahun 2003 menyatakan bahwa pendidik merupakan tenaga professional yang memiliki suatu tugas yaitu merencanakan dan melaksanaan suatu proses pembelajaran, melakukan peniaian terhadap hasil belajaran, melakaukan pembimbingan dan pelatihan.

Adapun ciri-ciri suatu profesi yaitu :

a. Mempunyai keahlian dan pengetahuan khusus yang sesuai dengan dengan pekerjaan yang didapat dari pendidikan.

b. Pada umumnya tenaga professional merupakan anggota suatu oganisasi profesi.

c. Adanya suatu badan tertentu yang menghasilkan teaga-tenaga profesiaonal dengan system pendidikan tertentu.

d. Terdapatnya suatu tata aturan yang mengatur para tenaga profesi dalam menjalankan tugasnya.

\section{2) Pendidik dan Profesi Pendidik}

Guru adalah pendidik professional dengan tugas utama mendidik, mengajar, membimbing, mengarakan, melatih, menilai serta mengevaluasi para siswa.

Secara formal guru adalah seorang pengajar atay tenaga pendidik di sekolah baik disekolah negeri ataupun swasta yang memiliki kemampuan khusus sesuai dengan jenjang pendidikan yang ia tempuh.

Profesi guru dilaksanakn berdasarkan prinsip-prinsip :

a. Guru harus memiliki bakat, minat panggilan jiwa serta memiliki jiwa idealisme.

b. Setiap guru memiliki komitmen yang tinggi untuk meningkatkan mutu pendidikan.

c. Setiap guru mengemban tugas sesuai dengan laatr belakang pendidikannya.

d. Setiap guru harus bertanggung jawab dengan tugas yang dia pikul.

e. Penghasilan yang diterima oleh guru sesuai dengan prestasi kerja yang ia capai.

Setiap pekerjaan professional memiliki suatu aturan atau kode etik yang mengatur para pekerjanya agar tetap professional dalam menjalankan tugasnya.

Kode etik guru adalah suatu kumpulan nilai-nilai dan norma yang tersusun yang harus dipatuhi oleh setiap guru dan jika para guru melanggar aturan atau norma tersebut maka guru bersangkutan akan mendapatkan sanksi sesuai dengan pelanggaran yang telah ia lakukan.

Tujuan kode etik guru adalah : 
a. Mengatur tata aturan setiap guru dalam bertingkah laku dalam menjalankan tugasnya sebagai guru.

b. Untuk meningkatkan profesionalitas para guru dalam menjalankan tugasnya.

c. Untuk meningkatkan mutu dari para guru.

Kode etik guru merupakan suatu pedoman yang mengatur hubungan antara guru dengan guru, guru dengan siswa, guru dengan orang tua murid, guru dengan pemimpin, guru dengan masyarakat, dimana hal ini dilakukan dalam rangka kepentingan perkembangan para peserta didik.

\section{3) Tenaga Kependidikan}

Tenaga kependidikan meliputi kepala sekolah, pengawas satuan pendidikan, tenaga perpustakaan, tenaga administrasi, tenaga labor, pamong belajar, petugas kebersihan, dan serta teknisi yang bertugas menunjang kelancaran proses pendidikan .

\section{KESIMPULAN}

Pentingnya mempelajari administrasi pendidikan adalah kita dapat mengetahui bahwa administrsi itu adalah suatu lembaga pendidikan yang merupakan suatu sumber utama manajemen dalam mengatur proses belajar mengajar dengan tertib sehingga terciptanya suatu tujuan terpenting pada lembaga pendidikan tersebut.

Profesi adalah suatu jabatan atau pekerjaan yang menuntut keahlian dari para anggotanya. Artinya, tidak bisa dilakuakan oleh sembarang orang yang tidak terlatih dan tidak disiapkan secara khusus untuk melakukan pekerjaan itu. Tenaga kependidikan adalah anggota masyarakat yang mengabdikan diri dan diangkat untuk menunjang penyelenggaraan pendidikan. Yang termasuk dalam tenaga kependidikan adalah : kepala satuan pendidikan, pendidik dan tenaga kependidikan lainnya.

\section{Daftar Pustaka}

Afriansyah, H. (2019). Administrasi dan Supervisi Pendidikan. Padang: osf.io. Retrieved from http://doi.org/10.17605/OSF.IO/TZ4VF 